\title{
Development of Problem Based Learning E-modules on Corrosion Materials Class XI SMA/MA
}

\author{
Rabiul Henita Yulia Putri ${ }^{1}$, Hardeli ${ }^{2}$ \\ ${ }^{1}$ Department of Chemistry, Padang State University, Jl. Prof Hamka, Air Tawar Barat, Padang, West Sumatera, \\ Indonesia \\ ${ }^{2}$ Department of Chemistry, Padang State University, Jl. Prof Hamka, Air Tawar Barat, Padang, West Sumatera, \\ Indonesia
}

Corresponding Author: Rabiul Henita Yulia Putri

\begin{abstract}
Problem-based learning-based e-modules are teaching materials in electronic form that support independent learning. This study aims to produce teaching materials in the form of emodules based on problem based learning on corrosion material for class XII SMA/MA. The type of research conducted is in the form of educational design research using the Plomp model with three stages, namely preliminary research, (2) prototyping stage, and (3) assessment phase. The e-module was validated by five validators consisting of two UNP chemistry lecturers and three chemistry teachers. The research instrument used was a validity questionnaire; the data obtained were analyzed using Aiken'V. The results of data analysis showed that the e-module based on problem based learning on corrosion material for class XII SMA/MA obtained an average value of 0.87 with valid criteria. The results of this study indicate that the developed e-module is valid as a teaching material for corrosion material for class XII SMA/MA.
\end{abstract}

Keywords: E-module based on problem based learning, corrosion, educational design research, Plomp development model.

\section{INTRODUCTION}

Corrosion is an SMA/MA chemical material that is studied in class XII in the first semester. Corrosion is metal damage due to electrochemical processes, corrosion can cause severe damage to buildings, bridges, ships, cars, and others ${ }^{[1]}$. Corrosion material contains factual, conceptual, and procedural knowledge that requires an understanding of the concept. The learning process must be carried out as well as possible according to the 2013 curriculum. Improvement and improvement of the quality of education are inseparable from various efforts, one of the government's efforts is to implement and develop the 2013 curriculum. The 2013 curriculum has been established as part of improving the quality of education in Indonesia from all levels of three domains, namely: knowledge, attitudes, and skills ${ }^{[2]}$. Based on the Regulation of the Minister of Education and Culture Number 22 of 2016 concerning process standards, there are several learning models that are prioritized in the implementation of the 2013 curriculum including discovery learning, inquiry learning, problem based learning, and project based learning models ${ }^{[3]}$. Problembased learning (problem based learning) is a learning model that presents contextual problems that aim to stimulate students to learn. In the learning process students work in groups to solve problems. Problem-based learning is a model that directs students to "learn how to learn", working in groups to find solutions to problems ${ }^{[4]}$. The learning process requires teaching materials, teaching materials are all forms of materials in the form of a set of materials that are systematically arranged that are used to assist teachers in carrying out learning 
activities and are used by students to obtain information ${ }^{[5]}$.

Examples of commonly used teaching materials are handouts, textbooks, modules, LKPD (Student Worksheets), models or mockups, audio teaching materials, interactive teaching materials, and so on. Teaching materials in learning function to help the teacher's limitations in conveying information or limited time in the learning process. One of the teaching materials that is often used is the module. The module is one of the teaching materials in the form of print which is designed to be studied independently by students in learning and outside learning hours. The module is an independent medium because it contains instructions for its use, so that students can learn independently ${ }^{[6]}$. The 2013 curriculum changes also refer to the changing demands of the 21st century. The characteristics of the $21 \mathrm{st}$ century are characterized by the presence of information that can be accessed anywhere, faster computing due to using machines, automatic access to all routine work, communication that can be done from anywhere and anywhere. The 21 st century is marked by the era of the industrial revolution 4.0, the world of education in the era of the industrial revolution 4.0 is in a period of knowledge with an extraordinary acceleration of knowledge increase ${ }^{[7]}$.

With the development of science and technology (IPTEK), teaching materials in the form of modules can be developed into electronic form. E-modules are self-study materials that are systematically arranged to achieve learning objectives which are presented in an electronic format. The use of electronic modules is very easy to understand so that it can be used as a good learning medium. E-modules contain animations, videos, pictures, and others that will help students be more interactive with the material ${ }^{[8]}$. Several studies that have been conducted show that e-modules based on the PBL (problem based learning) approach are very practical and help students in learning such as in molecular shape Material ${ }^{[9]}$, colligative properties of solutions, colloid system ${ }^{[10]}$, and several other studies such as Development of scientific approach based on discovery learning module ${ }^{[11]}$, Developing a discovery learning module on chemical equilibrium to improve critical thinking skills of senior high school students ${ }^{[12]}$.

The COVID-19 pandemic, it has a huge impact on health, education, and the economy. The current situation is that the government has decided to shift learning online, where the use of technology is already very sophisticated. Online learning currently requires teaching materials, electronic learning media by utilizing existing technology, such as e-modules (electronic modules).

Based on the distribution of questionnaires that have been carried out at SMAN 5 Padang, SMAN 5 Solok Selatan, and SMAN 4 Solok Selatan, it shows that teachers still use textbooks, LKPD, in the learning process so that the teaching materials used have not been adapted to the times (21st century). The demands of the 2013 curriculum expect students to be skilled in using media, technology, information, and communication (ICT) needed in the 21 st century. Based on the questionnaire that has been distributed, teaching materials are needed that take advantage of technological advances and can increase motivation and ask students to learn and support online learning.

Based on the above background, the authors conducted research on the development of e-module corrosion based on PBL (problem based learning) which aims to help students develop critical thinking skills, train independence in learning, and provide opportunities for students to build their knowledge through the problems presented by the teacher, teacher on corrosion material. This research is entitled "Development of Problem Based Learning-Based E-modules on Corrosion Materials for class XII SMA/MA". 


\section{LITERATURE REVIEW}

Corrosion is one of the chemical materials in class XII SMA which contains factual, conceptual, and procedural knowledge so that students are required to seek more information from various sources, discuss to solve problems. The teaching materials used in the learning process are in the form of textbooks, LKPD. However, the use of electronic-based teaching materials is still very rarely used in the learning process. Therefore, it is necessary to have teaching materials in the form of e-modules based on problem-based learning. Teaching materials in the form of e-modules based on problem based learning on corrosion materials for class XII SMA/MA that have been designed will be tested for feasibility through validity tests. The validity test was carried out by chemistry lecturers, chemistry subject teachers, and XII SMA/MA students.

\section{MATERIALS \& METHODS}

The type of research conducted is Educational Design Research using the Plomp model ${ }^{[13]}$. The stages in the Plomp model can be seen in Figure 1.

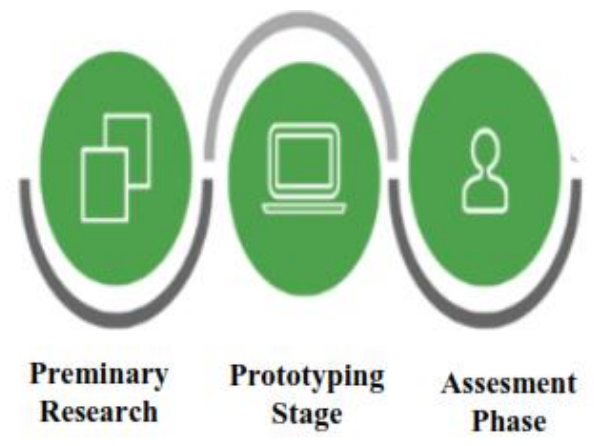

Figure 1. Stages of the Plomp development model

The development of the plomp model begins at the preliminary research stage, at this stage needs and context analysis, literature study, and conceptual framework development are carried out. in the second stage, namely the prototyping stage, which consists of prototypes one to four. This research is limited to validity only (prototype III). Validation was carried out by five validators, two chemistry lecturers, and three chemistry teachers

\section{Statistical Analysis}

Data analysis on validation using Aiken's V [14]. Aiken's $\mathrm{V}$ formula as follows:

$V=\frac{\Sigma s}{\ln (c-1)]}$

$s=r-l o$

Description:

$\mathrm{r}=$ Validator selection category score

$\mathrm{n}=$ Number of validators

lo $=$ Lowest validity assessment number $(\mathrm{lo}=1)$

$\mathrm{c}=$ Highest validity assessment number $(\mathrm{c}=$ 5)

The assessment of validity criteria based on the Aiken V scale can be seen in the journal Aikens'V.

\section{RESULT}

\section{A. Preliminary Research \\ 1) Needs and context analysis}

The results of the needs analysis, namely filling out questionnaires for teachers and students, were found that teachers still use textbooks, LKPD, in the learning process so that the teaching materials used have not adapted to the times (21st century). In addition, the needs analysis is carried out by analyzing the demands of the 2013 revised 2018 curriculum, where learning is studentcentered, independent learning, and students are skilled in using media, information, and communication technology (ICT) in the learning process. Nugraha's research (2015) shows that e-modules can support students' independent learning. Context analysis is carried out on Basic Competencies (KD) on corrosion material which can be reduced to Competency Achievement Indicators and make learning objectives.

\section{2) Literature review}

At this stage, the search for sources and references related to research activities is carried out to see an overview of the learning process on corrosion materials. Books, journals, articles, theses, etc. Can be used as sources and supporting references in 
research activities. The results can be seen in the attachment.

\section{3) The Conceptual framework or theoretical development}

This conceptual framework refers to all the ideas that underlie the product. The conceptual framework connects the concepts that are the object of this research.

\section{B. Prototyping Stage \\ 1) Prototype I}

In prototype I, an e-module based on problem-based learning was produced which has several components, namely the e-module has several components including cover, e-module profile, instructions for use, learning competencies, concept maps, activity sheets, evaluations, and answer keys.

\section{2) Prototype II}

The second prototype stage is formative in the form of self-evaluation. Self-evaluation is carried out with a checklist system of the parts that must exist in the problem-based learning-based emodule on corrosion. If there are still missing parts, revisions will be made to produce prototype II.

\section{3) Prototype III}

Formative evaluation on prototype III resulted from one to one evaluation and expert review on prototype II.

\section{a. Expert reviews}

The resulting prototype II was validated by five validators in the field of chemistry consisting of two Chemistry lecturers at FMIPA UNP, two teachers at SMAN 4 Solok Selatan, one chemistry teacher at SMAN 5 Solok Selatan.

\section{b. One to one evaluation}

One to one evaluation conducted interviews with three students of SMAN 4 Solok Selatan with different abilities (high, medium, and low based on the recommendation of the chemistry teacher).
After that, an assessment of the results of the evaluation of the product being developed is carried out. The evaluation results obtained are analyzed so that the validity value of the e-module will be obtained. If necessary revisions will be made by the recommendations suggested by the validator. The revisions were made to improve the quality of the prototype to produce a valid prototype III.

\section{DISCUSSION}

This research produces an e-module based on problem based learning on corrosion material for class XII SMA/MA. The validity value obtained using Aikens'V is 0.87 , the criteria for valid or not can be seen in the aikens'v table, where the resulting $\mathrm{V}$ must be higher than the $\mathrm{V}$ table. The value of $\mathrm{V}$ is for five raters and five number of rating categories categories with an error level of $5 \%$, which is 0.80 .

\section{a. Content component assessment}

Based on the data obtained from the validity of the e-module based on problem based learning, the average content feasibility is 0.85 with a valid category. The aiken' $\mathrm{v}$ average shows that the problembased learning-based e-module on the corrosion material developed has been by the basic competencies (KD) requirements, namely 3.5 and 4.5 in 2013 revised 2018 Curriculum syllabus, must describe the Basic Competencies, Indicators, and learning objectives to be achieved by students ${ }^{[15]}$.

\section{b. Presentation component assessment}

Based on the validation table for the presentation component of the problem based learning e-module, the average presentation component is 0.86 with a valid category. This shows that the problem-based learning e-module on the corrosion material developed has been presented by the indicators and learning objectives that have been formulated. The presentation of the emodule is structured based on the steps/syntax of PBL (Problem Based Learning), namely the orientation of 
students to problems, organizing students to learn, investigating in groups, developing and presenting the work, and analyzing and evaluating the problem solving process ${ }^{[16]}$.

\section{c. Language component assessment}

The average acquisition of aikens'v on the linguistic component is 0.83 with a valid category, this value informs that problem-based learning-based e-modules on corrosion material are communicative and use clear and consistent language in the use of symbols/symbols. The language used is by good and correct Indonesian rules so that it does not confuse confusion in understanding for students.

The use of language in the module should use sentences that are simple and easy to understand, sentences must be patterned in such a way that they become communicative and familiar to students. Communicative writing affects students' learning interests ${ }^{[17]}$.

\section{d. Graphical component assessment}

The average acquisition of the graphic component is 0.93 with a valid category, this shows that the problem-based learning-based e-module on the corrosion material produced has legible writing, has a layout or cover display between the parts in an attractive e-module and pictures, videos and animations that are displayed are observed.

\section{CONCLUSION}

Based on the results of research conducted on e-modules based on problem based learning on corrosion materials, it can be concluded that:

1. E-modules based on problem based learning on corrosion material for class XII SMA/MA can be developed using the Plomp development model.

2. E-module based on problem based learning on corrosion material for class XII SMA/MA which was developed has a $\mathrm{V}$ value of 0.87 with a valid category.

Acknowledgement: None

\section{Conflict of Interest: None}

\section{Source of Funding: None}

\section{REFERENCES}

1. Chang, Raymond. 2003. Kimia Dasar: Konsep-konsep Inti. Jilid 2 Edisi ketiga. Jakarta; Erlangga

2. Fauziah, R. Ade, G.A., dan Dadang, L.K. 2013. Pembelajaran Saintifik Ektronika Dasar Berorientasi Pembelajaran Berbasis Masalah. Jurnal Inovetec. Vol IX, No 2.

3. Kemendikbud. 2013. Materi Pelatihan Guru: Implementasi Kurikulum 2013. Jakarta : Kemendikbud.

4. Majid, A., dan Chaerul R. 2014. Pendekatan Ilmiah dalam Implementasi Kurikulum 2013. Bandung: Rosdakarya.

5. Kemendiknas. 2010. Juknis Pengembangan Bahan Ajar SMA. Jakarta : Direktorat Pembinaan SMA

6. Departemen Pendidikan Nasional. 2008. Pengembangan Bahan Ajar. Jakarta: Departemen Pendidikan Nasional. Direktorat Jenderal Manajemen Pendidikan Dasar dan Menengah, Direktorat Pembinaan Sekolah Menengah Atas.

7. Anwas, Oos M. 2013. "Peran Teknologi Informasi dan Komunikasi Dalam Implementasi Kurikulum 2013". Jurnal Teknodik, Vol 17. No. 1 Hal 494

8. Sugianto, Doni, Ade G.A., dan Siscka E,. Yuda M. 2013. "E-modul: Multimedia Flipbook Dasar Teknik Digital. INOVATEC Vol IX, No 2

9. Siregar, A.D, dan Leni K. Harahap. 2020. "Pengembangan E-Modul Berbasis Project

Based Learning Terintegrasi Media Komputasi Hyperchem Pada Materi Bentuk Molekul". Jurnal Penelitian Pendidikan Sains. Vol 10, No 1 Hal 19251931

10. Ellizar, E., H. Hardeli, S. Beltris, and R. Suharni. 2018. "Development of Scientific Approach Based on Discovery Learning Module." IOP Conference Series: Materials Science and Engineering 335 (1). https://doi.org/10.1088/1757899X/335/1/012101.

11. Ellizar, E., S. D. Putri, M. Azhar, and H. Hardeli. 2019. "Developing a Discovery Learning Module on Chemical Equilibrium to Improve Critical Thinking Skills of Senior High School Students." Journal of 
Physics: Conference Series 1185 (1). https://doi.org/10.1088/1742-

$6596 / 1185 / 1 / 012145$.

12. Saputri, A. dkk. 2017. "Pengembangan Emodul Berbasis PBL Berbantuan Instragram Pada Materi Koloid Kelas XI MIPA. Jurnal Pendidikan Kimia: Universitas Jambi

13. Plomp, T., \& Nieveen, N. (2007). An Introduction to Educational Design Research. Procedings of the Seminar Conducted at the East China Normal University, Shanghai (PR China) November 23-26,2007.

14. Aiken, L. R. (1980). Content validity and reliability of single items or questionnaires .Educational and Psychological Measurement, 40(4), 955-959.
15. Departemen Pendidikan Nasional. 2008. Pengembangan Bahan Ajar. Jakarta: Departemen Pendidikan Nasional, Direktorat Jenderal Manajemen Pendidikan Dasar dan Menengah, Direktorat Pembinaan Sekolah Menengah Atas.

16. Hosnan, M. 2014. Pendekatan Saintifik dan Kontekstual dalam Pembelajaran Abad 21. Bogor: Ghalia Indonesia.

17. Hamdani. 2011. Strategi Belajar Mengajar. Bandung: CV Pustaka Setia

How to cite this article: Putri RHY, Hardeli. Development of problem based learning emodules on corrosion materials class XI SMA/MA. International Journal of Research and Review. 2021; 8(8): 516-521. DOI: https:// doi.org/10.52403/ijrr.20210870 